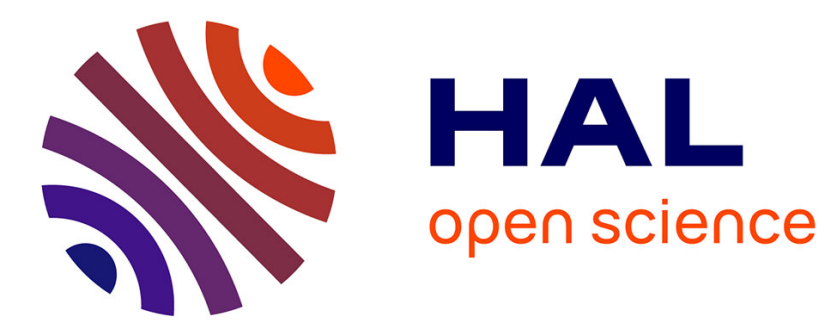

\title{
Lagos Koolhaas and Partisan Politics in Nigeria
}

Laurent Fourchard

\section{To cite this version:}

Laurent Fourchard. Lagos Koolhaas and Partisan Politics in Nigeria. International Journal of Urban and Regional Research, 2010, 35 (1), pp.40-56. hal-00653061

\section{HAL Id: hal-00653061 \\ https://hal.science/hal-00653061}

Submitted on 17 Dec 2011

HAL is a multi-disciplinary open access archive for the deposit and dissemination of scientific research documents, whether they are published or not. The documents may come from teaching and research institutions in France or abroad, or from public or private research centers.
L'archive ouverte pluridisciplinaire HAL, est destinée au dépôt et à la diffusion de documents scientifiques de niveau recherche, publiés ou non, émanant des établissements d'enseignement et de recherche français ou étrangers, des laboratoires publics ou privés. 


\title{
Lagos, Koolhaas and partisan politics in Nigeria ${ }^{1}$
}

\author{
Laurent Fourchard, Fondation nationale des sciences politiques,
} Centre d'etudes d'Afrique Noire, Université de Bordeaux

\section{Introduction}

On $20^{\text {th }}$ of April 2007, in Ikeja in the northern suburb of Lagos, Bola Tinubu, outgoing governor of Lagos state and its most powerful leader addresses a 5000 strong militant crowd of his party (the Action Congress, AC) five days after his candidate, Tunde Fashola had been elected as governor of Lagos state. The results of the elections, proclaimed by the Independent National Electoral Commission (INEC) indicated that the party in power, the People's Democratic Party (PDP) had won 28 of the 36 states in the country, and Lagos was the only state in Southwestern Nigeria in the hands of the opposition. Governor Bola Tinubu warmly thanked the militants for the victory against the presidential party. After that, he expressed some grievances against the them, saying: "I am not happy with you. I gave for this electoral campaign, five millions Naira and Lagosians did not come to vote en mass for the party". And the militants complained in return: "five millions Naira! But it did not reach the grassroots!",2

This story speaks about some of the features of Nigerian partisan politics: the centrality of patron/client relationships; the role political parties came to play in that relationship; and a long history of opposition between Lagos state leaders and the Federal government. These features, albeit largely neglected in the recent literature, have also been central, to explain the way Lagos has been planned and routinely managed especially in the post-colonial period. I argue here that the partisan politics of local patrons, association and union leaders and political party leaders have shaped the way Lagos has been planned and not planned since the end of the colonial period. This argument goes against the vision of Lagos portrayed by Rem Koolhaas and his team, the Harvard Project on the City (Koolhaas and al, 2000). ${ }^{3}$

Since its first publications on Lagos, Rem Koolhaas has been commented on, quoted, criticized and lauded. Koolhaas refers to Lagos as an 'icon of West African urbanity [that] inverts every essential characteristic of the so-called modern city' (quoted in Enwezor, 2003: 113). Instead Lagos is the 'paradigm and the extreme and pathological form of the West African city' (Koolhaas and al, 2000). Despite the lack all the basic amenities and public services Lagos continues to function as a city because it is conceived as a series of selfregulatory systems which has freed itself from the constraint of colonisation and post independence town planning. Lagos illustrates the large-scale efficacy of systems and agents considered marginal, informal, or illegal: it is a celebration of informality which cannot be reduced to disorder as it generates economic dynamism and reveals the capacity of Lagosians to develop their own infrastructures This argument challenges 'traditional' urban studies

\footnotetext{
${ }^{1}$ The author would like to thank the following people for sharing their knowledge on Lagos and Ibadan: Olufunke Adeboye, Olutayo Adesina, Rufus Akinyele, Isaac Olawale Albert, Daniel C. Bach, Abubakar Momoh, Ayodeji Olukoju, Rotimi Suberu, Thanks also to the three referees for their comments on an earlier version of this paper.

${ }^{2}$ Personal observation, Ikeja, Lagos, 20 April 2007.

${ }^{3}$ At the time of submission of this manuscript the book by Rem Koolhaas and the Harvard Project on the City on Lagos: How it Works was not yet published.
} 
which have concentrated on public regulations and services and consequently caught the attention of many scholars especially those beyond the usual groups of specialists of the African continent. Actually, for Koolhaas, the continued functionality of Lagos and other megacities of the South as cause for revising existing theories about the functioning of urban systems (Rao, 2006: 226-7). The Harvard Project of the City suggests that rather than viewing the conditions of dysfunctionality as African ways of becoming modern, it is possible to argue that 'Lagos represents a developed, extreme paradigmatic case-study of a city at the forefront of globalizing modernity' (Koolhaas and al, 2000: 653).

In rehabilitating informality at work in Lagos, Koolhaas however has not avoided the risk of essentialising the (West) African city. The author rests on the supposition that poor cities do not seem to have achieved the features considered 'urban' in the West (Robinson, 2006: 91). Rather he promotes an essentialist vision of the 'African city' trapped within a category of ontological difference (Gandy, 2006: 390). In this process, the experience of the city is de-historicised (Fourchard 2007a; Gandy, 2005, 2006). Matthew Gandy is probably the author who has most undermined this vision of Lagos. Against the paucity of empirical data and the emphasis on the exceptional character of Lagos suggested by Koolhaas's team, Gandy has favoured an analysis which frames the experience of Lagos within a wider geopolitical arena of economic instability, petro-capitalist development and regional internecine strife. His historical perspective is developed in order to reveal how structural factors operating through both the colonial and post-colonial periods have mitigated against any effective resolution to the city's worsening infrastructure crisis (Gandy, 2006).

This article would like to complete this first approach in exploring an argument which is often missing in analysing contemporary Lagos: the centrality of partisan politics in shaping the form of the city. The Koolhaas team's vision of self regulatory systems is mainly based on an analysis of the so-called informal economy that underestimates the strength of power relations at street level and which does not pay attention to political parties / societal connections. I argue instead that the multiple and complex relationships of a set of powerful local actors with state institutions and political parties have been a central feature of the way Lagos has been thought, planned and not planned for decades.

A first section looks at the literature on informality and its connections to 'state decline' analysis in Africa and Nigeria. A second one looks at Lagos as a place of conflict between the Federal government and the major opposition party from the 1950s to date. The third section analyses the present day dispute over the number of local governments in Lagos state as a concrete illustration of this opposition. The last section presents some findings of an empirical study carried out in 2002, on markets and motor parks in Lagos and Ibadan, another millionaire city, $80 \mathrm{~km}$ north of Lagos. ${ }^{4}$ Results show similar trends in Lagos and Ibadan dominated by more taxation by the local state on markets while the politicisation of motor parks has become central in the electoral game of the $4^{\text {th }}$ Republic (1999 to date) and in the political economy of Lagos and many other Nigerian cities.

\section{A Informality and 'state decline' in Africa and Nigeria}

\footnotetext{
${ }^{4}$ A total of 600 questionnaires were administered to shop owners and street traders in four Ibadan markets. The same questionnaire was administrated to 300 traders in six Lagos markets and completed by personal interviews with market traders and local officials. If parts of these results have been published previously (Fourchard and Olukoju, 2007), this article is based on other sources coming from the same survey and completed by two other fieldworks, one done in Ibadan in 2002 with local government officials, the other one done in April 2007 in Lagos and Ibadan among political leaders and other local government officials. Lagos and Ibadan based newspapers (especially, one of the main opposition newspapers, the Nigerian Tribune) and Nigerian published and unpublished materials not easily available outside Nigeria have also been used.
} 
The Koolhaas team's interpretation of Lagos as a globalised modern city, a 'mega city which works' has attracted more interest within the academic community interested by cities worldwide than in Nigeria itself where his essay has been poorly debated in the main universities of the country (see however, Konu, 2002). For some scholars, this interpretation gives the possibility to get away from urban planning trapped in an almost entirely negative contemplation of Lagos's deficiencies and failures (Haynes, 2007: 132): instead it brought a more positive vision of African cities (de Boeck, 2006) and of the capacity of people to create parallel infrastructure systems in transportation and trading (Larkin, 2004: 310). Others have criticized the architect for his ignorance of the suffering of the poor (Packer, 2006), for overestimating the flexibility of such a system (Thrift, 2005: 138) or alternatively for not explaining what exactly this modernity means (Hofmeyer and Pauwels, 2002). James Ferguson recently considered that his analysis is imbedded in a burst of 'new thinking' about urban poverty which sees in the informal economy not a pool of unemployed or underemployed workers, but a promising site of economic growth and dynamism which creates jobs: 'informalities that not long ago were automatically identified as symptoms, problems or monstruosities are today increasingly likely to be reinterpreted as assets, capacities, or opportunities' (Ferguson, 2007: 74-5). Admittedly this trend is part of a well known optimism in which international agencies expect the informal sector to absorb additional labour due to the economic crisis and the reduction of number of workers within the formal sector (Rakodi, 1997: 62).

The expansion of that informal sector has sometimes been linked to economic decline, the privatisation of state assets, the reduction of the size of public enterprises and the widespread crisis of state capitalism especially after the cold war. In Africa especially, the implementation of structural adjustment reforms in the 1980s and the 1990s have led, according to some authors, to a general informalisation of the urban economy (Chen, 2001; Hansen and Vaa, 2004; Zelela, 1999). It has, however, been argued that the distinctions between formality and informality were so blurred that a rigid delimitation was useless. Economists have noted the inconsistencies of the formal-informal dualism and the weakness of most criteria that discriminate between the two categories (Rakowski, 1994, Sindzingre, 2006; Chen, 2006). Jane Guyer also notes that the 'neoliberal moment' has not necessarily decreased formalisation so much as extended it piecemeal. Every NGO has to be registered; every multinational requires an export licence, every international financial institution links to national government bodies and financial institutions, to the bank and eventually to their customers (Guyer, 2004: 187). A trend of study has thus largely revaluated the role of politics in the making of informality in Africa, especially concerning vendors and traders. On the one hand, the relationships between urban vendors and local authorities report crackdowns, evictions and harassment by agents of local authorities and associations have been formed to survive and prosper despite the state's continuous controlling measures (Lindell, 2008; Simone, 2004; Tripp 1997). On the other hand, the expansion of informality may also involve a large degree of political networking. Vendors may make links with political parties in order to gain support for their position, they may mobilize their members for local patrons and get organised to defend their interests within the local government (Grest, 1995; Hansen, 2004; Heilbrunn, 1997; Skinner and Valodia, 2003). As mentioned by Janet Roitman (2007) political activism and civil disobedience can bring regulated and unregulated traders together and reveal an 'economic citizenship at work'.

Despite this body of work, the informal economy in Africa remains often associated with manifestation of the so called 'state decline' or 'state weakness'. This is well illustrated by the infrastructure crisis in Lagos. According to Koku Konu (2002: 240), Lagos has changed from a well-planned city to a chaotic city in the last two decades while Rem 
Koolhaas (2002: 183) considers that Lagos has escaped the organisation of the 1970s planners. More generally, there is a strong emphasis in the literature on the effect of the economic crisis of the 1980s and 1990s, of the Structural Adjustment Policies (SAP) and IMF solutions in many African countries including Nigeria (Wall, 2001; Osaghae, 1998). Accordingly, this period has largely accelerated the decline of infrastructures throughout Nigeria. While the effect of the economic crisis should not been underestimated - especially on the increase in the percentage of poor people in Nigeria this focus tends however to underestimate other time-periods during which economic growth was important (1945-81 and 2000-08) and which gave a subsequent increase of the national budget in Nigeria.

In this framework, some scholars have insisted on the dramatic erosion of the state in Africa since the 1990s. This erosion has opened up a space for numerous actors, such as informal traders, warlords, militia groups, local associations which have led to the end of the postcolonial state (Young, 2004) or to the rise of many weak states in the continent (Reno, 2004). More specific analysis on Nigeria also portrayed state decline, the incapacity of the state to control its entire territory, the development of numerous forms of collective violence throughout the country and the risk for Nigeria to become a country without state (Clapham, Herbst and Mill, 2006; Bach, 2006). Eventually, the development of state failure and weak state analyses in the last fifteen years have also looked at the poor performance of the state in delivering public goods, especially in Africa. Interestingly, more recent analyses have now integrated an urban dimension in looking at the relationship between cities and state formation or cities and state fragility. ${ }^{5}$

These last analyses do not avoid the trap of isolating the state from the society while many authors have for long now challenged the conventional dichotomies of state versus society, legal versus illegal, or scientific planning versus private self interest in various states of the South. Actually, many institutions in Africa operate in the twilight between state and society, between public and private and what characterised them is their movement in and out of a capacity to exercice public authority (Lund 2007: 6). Instead of looking at violence in Nigeria as the manifestation of state decline it is worth to analyse it as part of a political order in which state and non state actors (ministers, governors, godfathers, political party and union leaders) have been playing a decisive role (Fourchard, 2007b). It is also obvious that oil money is redistributed through the immense state machine (36 states and the 776 local governments) and through an impressive network of clients. At the core of the system therefore lay the patron/client relationships. As elsewhere in Africa, patrons are at the head of social networks and connect their clients with government officials and political leaders (Bayart, 1993: 217). This set of patron/client relationships or political clientelism is not specifically African, it is at the core of political systems of countries as diverse as Japan, Italy, Brazil, Mexico and Argentina (Kitschelt and Wilkinson, 2007; Stokes, 2005; Scheiner, 2006). It is not the place here to review national variations of clientelist systems, however, two specific points should be mentioned.

First, it is difficult to assess fundamental differences of clientelism between the cities and the country in Africa and Nigeria. In Italy and Austria increasing urbanisation helped increased the antagonism toward the clientelist system while continued urbanisation may also undercut the Japanese clientelist system (Scheiner, 2006: 89). In Africa, Mahmood Mamdani (1996) considers that colonial rule created a clear opposition between a tribal, despotic and largely clientelist rural power and an emergent and democratic civil society based in towns and cities. Such opposition tends however to undervalue the importance of urban-rural links in

\footnotetext{
${ }^{5}$ See for instance the programme on "Cities in fragile states", London School of Economics and Political Sciences, Crisis States Research Center."http://www.crisisstates.com/download/publicity/CitiesBrochure.pdf
} 
the making of African politics and to underestimate the force of clientelist relationships in towns and cities. It is thus not clear that the urbanisation trend in Africa undermines the clientelist system.

Second the importance of the patron/client paradigm is notoriously hard to measure, especially at the level of the party and the party systems (Hagopian, 2007: 587). If there is no quantitative survey done in Nigeria on the percentage of voters receiving goods from political party in exchange of votes, the patron/client paradigm seems to be prevalent both in Lagos and throughout Nigeria. It has been so at least since the colonial period and has been extended both by military and civilian regimes alike (Diamond, Kirk-Greene, Oyediran, 1997; Joseph 1987; Lewis 1996; Osaghae, 1998). Excellent monographs on the early colonial and early independence periods in Lagos have also considered this paradigm as central in shaping Lagos society (Baker, 1974; Barnes, 1991; Mann 2007). I thus consider after Bayart (1993) and Hibou (2004), that patron-client relationships and outsourcing of state functions to various political, religious and associational entrepreneurs (vigilante groups, market associations, union leaders and so on) are part of an ongoing process of state formation rather than the manifestation of state decline in Nigeria. ${ }^{6}$ Lagos is a privilege site for understanding this process through an analysis of state / 'informal' actor relationships as well as through the confrontation between its two major state powers.

\section{B Planning and partisan politics in Lagos}

Lagos throughout the $20^{\text {th }}$ century has effectively been the seat of two rival powers. On the one hand, it was the seat of the colonial and Federal government (191491) which was either dominated by a coalition of eastern and northern political parties during civilian regimes (1954-60, 1960-66, 1979-83) or by a northern clique during military regimes (1966-79, 1983-99). On the other hand, the dominant party in the Western region (the Action Group and its leader Obafemi Awolowo (1909-87) has most of the time been in the opposition to the Federal government. The party controlled the Lagos Town Council during the late colonial period and the First Republic (1954-66), one of its members, the 'awoist' Lateef Jakande was elected Governor of Lagos state during the Second Republic under a new political banner (Unity Party of Nigeria, UPN) (1979-83) while another 'awoist', Bola Tinubu was elected twice governor of Lagos State in the $4^{\text {th }}$ Republic (1999-2007) as a leader of a political party (Alliance for Democracy, AD) which is an off-shoot of the AG and UPN. Babatunde Fashola, the last Lagos governor elected in 2007, belongs to the same political family and was elected under the banner of the Action Congress (AC), an off-shoot of the AD. There is a thus a historical antagonism between Lagos based politicians and the Federal government and this has been particularly obvious in the contestation over the allocation of public resources by the Federal government. Among the various contentious issues, two had direct consequences on the planning of Lagos: the fight over the location of the capital and over the status of Lagos, and the permanent opposition between the Region (and Lagos state) and the Federal government concerning the main planning operations of the metropolis.

From Federal capital to a state capital

\footnotetext{
${ }^{6}$ Bayart and Hibou rely mainly on Weber's idea of discharge, a modality of exercising power which avoids the cost of a major administrative apparatus. It does not indicate the absence of state power or a government but is rather characteristic of situations or moments in history that are much less bureaucratised (Hibou, 2004:19).
} 
The location of the capital became a hotly debated issue in the early 1950s, in the framework of the negotiation of independence between the Colonial Office and nationalist parties. Intense debates were then preparing the future of the Nigerian constitution and the federal character of the state in which large internal power was given to three new powerful regions (Northern, Eastern and Western regions) (Adebayo, 1987). . The British administration, Northern and Eastern parties wanted Lagos to be the capital of Nigeria but dissociated to the Western Region. The reason was mainly financial: the port and the growing industrialisation of Lagos provided large resources for the state. To abandon Lagos to the Western Region included the risk of reinforcing the financial power of its dominant political party, the Action Group. The Action Group wanted to keep Lagos within the Western Region for the opposite reason and suggested to build a new capital in a central and neutral place. The Colonial Office eventually decided to keep Lagos as the capital directly administrated by the Federal government, a decision perceived by Obafemi Awolowo as a fiscal and economic suicide for the Western region. More than ten years later, the creation of Lagos state (1967) was also the result of a political opposition between the Federal government and the western Region. It has been interpreted in earlier studies as a response to the demand of Lagos politicians to have their own state (Parker, 1974: 59-60; Peil, 1991: 49-52). It should be mentioned however that Lagos state has been created with eleven other states the day before the secession of the Biafra war (27 May 1967). This represents the will of the Federal government to cut off the Western region from the sea, to dampen the autonomist sentiments of Yoruba leaders (Suberu, 2001: 88) and to once again minimise the influence of AG in that region. After the Civil war, the national reconciliation policy largely agitated for a politically neutral capital and decided the president Murthala Mohammed to build a new capital in Abuja at the centre of the country (1976) (Benna, 1989: 250-1). Abuja was selected because it was at the confluence of the three regional political forces while Lagos was still perceived by Northern politicians as an AG constituency (Abumere, 1989: 260-1). $80 \%$ of the national budget was now coming from the Niger delta petrodollars. The city port once deemed central for nationalist leaders was gradually becoming marginal for the new oil state. It took however fifteen years to build Abuja (1976-1991), and another ten years to move all ministries (1991-2000). This new national context radically modified the pace of public investments in Lagos, gradually but inevitably changing the federal capital into a state capital.

Planning and political conflicts

As the Federal government and AG became strongly opposed on the function, status and the administrative borders of Lagos city council and Lagos state, conflicts soon arose concerning the planning operations of the metropolis. In the mid 1950s, the necessity to have a modern capital with larger roads and without shacks in its central area proved to be a central argument for the government and its local body, the Lagos Executive Development Board (LEDB), the main planning instrument of the colonial government since the 1920s (Marris, 1962: 84). The scheme was, however, difficult to implement and was delayed because of the opposition of the residents and of the Lagos Town council dominated by AG which presented itself as advocate of the people to be displaced. The government accused AG of 'playing politics with epidemics' while AG accused the government of having selected the central area of Lagos Island for his slum removal which was its stronger political constituency. ${ }^{7}$ Both accusations were probably true: Lagos Island, the most densely area of the city, was hit by severe and recurrent plagues since the $19^{\text {th }}$ century while its two electoral

\footnotetext{
7 'AG against slum clearance scheme', Daily Service, 4 October 1955. 'Playing politics with epidemic' West African Pilot, 7 October 1955. 'Slum plan shelved till next year'. Nigerian Tribune, 4 November 1955.
} 
wards were the only ones to have elected without discontinuity AG councillors from 1950 to 1965 (Marris, 1962; Baker, 1974: 156-157).

The divergent view on the planning operations came to be reinforced at independence. In 1962, a UN team of experts came to Nigeria to evaluate key problems in metropolitan Lagos: traffic congestion, shortage of housing, lack of housing finance, large size of slum areas and insanitary conditions of most of the houses, lack of human resources and absence of a metropolitan government were considered to be more important problems to deal with urgently (Abrams and al., 1980). The Federal and the Lagos state military governments followed none of the UN team's recommendations except one: the building of road infrastructures which was mainly a response to the priority given to the development of individual cars over any other means of public transportation. Similarly instead of a housing policy, the practice of slum removals tended to become increasingly common: between 1973 and 1996, thirty six major forced migrations took place in Nigeria, two third of them in Lagos (Simone, 2004: 191-2).. In 1980, the same United Nation team came back to Lagos to conclude that problems identified in 1962 were identical but worse (Adams and al, 1980).

The poor performances of successive military governments appear to be more pronounced compared to Lagos state government during the Second Republic (1979-1983): in ten years, the military governors of Lagos state were only able to complete one waterworks to serve Festac town, a luxury residential quarter (4 million gallons of water a day) while in four years, the civilian government succeeded to build ten waterworks in different poor and middle class areas of Lagos (21 million gallons a day) (Olukoju, 2003: 69). Similarly, the number of primary schools built by Jakande is higher than all schools built by former military governors (Olowu, 1990: 76-77). The Governor also contested the policy of building more roads which led to more congestion instead of thinking to a mass transport system for the metropolis (Lagos State, 1981: 34). The 1981 project of a metro line as well as the Lagos master plan of 1980 were both ambitious projects for the metropolis but they were abandoned after the return of the military to power in 1983 (Gandy, 2006: 382; Fourchard and Goddard, 2002).

The two following decades were marked by the decline of oil price, the return of several brutal military regimes (1983-1999) and the implementation of Structural Adjustment Programme (SAP) in 1986, which drastically reduced the Federal state budget while large sums of federal money disappeared at an increasing level.The economic crisis and SAP have undoubtedly limited the number of new projects in Lagos but a more central reason was the reluctance of the national government to make long-term commitments to Lagos in view of the decision to shift the capital which required heavy investments (Olowu, 1991: 151). It is not surprising though that the last major planning operations and provisions of basic services for Lagos came out only recently with the return of a new elected government (Gandy, 2006: 385). In 2006, Governor Bola Tinubu has initiated an important project of revitalisation of the historical core of Lagos Island in order to reverse the economic and environmental decline of the two last decades (Lagos State, 2006).. In the global city competition, the intention is to make Lagos 'comparable to other major cities in the world' and thus to be conducive for foreign investments. In the Nigerian case however, the national political dimension is obviously at play. For the Governor Tinubu, 'our vision is to make Lagos State the reference point of harmonious physical development in Nigeria trough best practices and physical planning and development matters'.

This too brief overview of failed planning projects in Lagos is thus mainly related to the historical opposition between Lagos and South-Western based politicians on the one hand and the Federal government on the other hand. The construction of the city of Abuja during a period of budget restriction (1980s and 1990s) indicates that the 'crisis of infrastructure' in Lagos is mainly the result of a political choice. The battle over the census of Lagos state population and its number of local governments perfectly illustrates this confrontation. 
In January 2007, the Federal government released the breakdown by state of the 2006 new federal census figures: Lagos state, with nine million inhabitants, is the second most populated state in Nigeria behind Kano state (in the North) with 9,38 million inhabitants. The federal census was soon contested by the Lagos state government which organised its own census and found 17 million inhabitants, a figure considered as invalid and unconstitutional by the Federal government. Censuses have always been a highly sensitive political affair because it partly determines the amount of federal fund allocation to the states. Previous national censuses have been grossly manipulated by the government and rejected by political leaders from the South mainly because the Southern Regions or states were declared to be less populated than the Northern regions (Udo, 2000: 14; Olowu, 1990: 155). Today, Lagos state figure is in a way supported by the United Nations population projection which states that Lagos will reach 25 million inhabitants in 2015 (Nations Unies, 1999: 15). But one of the core arguments of Lagos politicians is to indicate that Lagos state could not be less populated than Kano state ${ }^{8}$. These two opposite figures have obvious consequences in terms of federal allocations, of political representation at the House of Parliament and at the Senate, in the planning of Lagos and in the ongoing contestation over the number of local governments in Lagos.

The $4^{\text {th }}$ Republic constitution has effectively recognised twenty local governments in Lagos state. But since March 2004, Lagos state has created 37 additional local governments considered as illegal by the Federal government which has thus decided to withhold allocations to all Lagos State local councils.

According to Lagos local government chairmen interviewed in April 2007, the reasons for creating new local government councils are twofold. Firstly, the higher number of local governments in many other states of the federation is perceived as an injustice by Lagos leaders. Kano state is for Lagos politicians the new state to be compared with since the 2006 census:

'We cannot understand why Kano State passed from 20 local governments in 1976 to 77 today while its constituency has been reduced by the creation of Jigawa state in 1991. We cannot understand why Lagos state passed from 12 local governments in 1976 to only 20 today while its constituency is the same and the number of inhabitants is twice the number of Kano state according to the 2007 Lagos state census. Local governments are for a long time needed in Lagos and we have decided to fight the perpetual marginalisation of Lagos by Abuja in creating new local government councils'.

Secondly political leaders in Lagos, like those in the Delta region, are protesting against the federal centralisation of tax revenues notably the duties on export in Abuja, a process which started with the civil war. According to Lagos local government chairmen, having more local government is a way for Lagosian people to have parts of the taxes which have been confiscated by the Federal government in the last three decades. If these explanations have some validity, local government creations should also be understood as a way for Lagos state party to extend its power at the local level and to raise popular support among the voters. All local government chairmen are active members of the state party while people perceived these new local councils as opportunities to get positions, employment and a closer access to state government resources. But as a result of the conflict between Lagos and Abuja, Lagos local governments have not received any

\footnotetext{
${ }^{8}$ Interviews with Local government chairman in Lagos, April 2007.

${ }^{9}$ Interviews with local government chairmen, April 2007, Ikeja, Lagos.
} 
federal allocation in the last five years. Such process is however not unique in Nigeria. Ibadan local government chairmen interviewed in 2002 when Oyo state was in opposition also complained that revenue allocations of the Federal government was either not sent on a regular basis or even some years not sent at all.10

Clearly, local political landscape in Nigeria does not fit decentralisation policies promoted by international institutions as a way of strengthening democracy or economic development at the local level. There is rather a long history of domination of local governments by upper levels of government since the 1960s (Bello-Imam, 1996:115). The multiplication of the number of local governments during military regimes was a way of popularising at the local level illegitimate military governments while during civilian regimes, local governments were largely used as a way to extend political influences of the dominant state political party as it happened during the Second Republic when Lateef Jakande created 28 new local governments before being disbanded a few years later by the military government. This trend is not exclusively Nigerian however: instead several studies have indicated that the 1990s 'third democratic wave' in Africa as well as decentralisation measures have not necessarily undermined former authoritarian practices of the state but have rather facilitated the dominant political party to extend its local ramification to an unprecedented level (Crook and Manor, 1998; Loada and Otayek, 1995). Local governments are thus largely perceived by officials and leaders as a political resource for the party. The control of its two major revenues (markets and motor parks) has been more central in Nigerian partisan politics than in planning the city as such.

\section{Tapping the resources of the city: the politics of motor parks and markets}

The Harvard Project on the City sees the markets and motor parks in Lagos at the centre of a self-regulatory system of Lagos economic life. Oshodi, the main motor park and market in Lagos is portrayed as a success story made possible by the organisation of a set of local actors performing their role outside any public intervention The understanding of the working of motor parks and markets is however not possible outside their relationship to state officials and party leaders. Markets and motor parks are the two main areas in which planning have largely been dominated by partisan politics for decades in Lagos, in Ibadan and in many other Nigerian cities. The taxes provided by these two places constitute the main local sources of revenue for local government. It is argued here that the politicisation and lack of planning of these two kinds of public space in Nigerian cities represent two simultaneous processes. It is also suggested that a brutal change from a wellplanned city to a chaotic city does not fit the political history of markets and motor parks in Nigeria.

Markets and taxation

All along the $20^{\text {th }}$ century, markets have been contested places of power between market women, traders and the state. Controlling places of trade was part of the colonial project (in order to increase taxation, to control prices, to improve hygienic behaviour, to limit street trading) but at the same time, the colonial administration was forced to tolerate urban institutions which were beyond its control. Large parts of the pre-colonial city of Ibadan were left in the hands of 'traditional authorities' while the rapid growth of Lagos, imposed the administration to delegate power to local chiefs and community organisations. Archival records testify the difficulty of the municipal authority to forbid street trading and stalls in and

\footnotetext{
${ }^{10}$ Interview with the Ibadan North West and South East Local Government Chairmen, May 2002.
} 
around the main commercial centres as well as in the large 'indigene' city. As soon as 1932, the administrator of the colony complained that 10000 non registred traders were operating in a town which had only 100000 inhabitants. In the late 1950s and early 1960 the main avenues in the commercial centre (Lagos Island) were occupied by an army of merchants, street traders, by goods and parked cars. Increasingly, from the 1960s onward sometimes before, residents in the inner city of Lagos and Ibadan turned their ground floor into shops and their front into stalls. The transformation of a well planned colonial city to a chaotic city is more a myth than a historical trajectory shaped by a colonial-postcolonial continuum.

Levying taxes on markets, a function devolved to local governments from the 1950s onward is an indicator of an increasing intervention of Nigerian officials in market affairs. Historically, markets in Yoruba towns and cities are owned by local communities or private landlords. Today, these landlords still owned a majority of shops and stalls in the historical centre of Lagos (Lagos Island) and Ibadan (Oja Oba). Since the 1970s however, local and state governments have reinforced their control over market places. This is particularly clear in Ibadan: in 1971, only three markets among the 26 surveyed belonged to the municipality, most of the other markets belonged to local communities and consequently were paying fees to local owners (Vagale, 1974: 9). Today thirteen markets among the 38 markets surveyed belong to one of the five local governments and consequently registered traders pay their fees to local government officers (Ibadan survey, 2002). Moreover in the late 1980s, military state government displaced several thousands of traders from the inner city where they were dependant from local owners and traditional leaders to two peripheral markets, Bodija and New Gbagi, respectively owned by North local government and Oyo state government. Together they constitute today the bigger markets of Ibadan with several tens of thousands of traders. A similar trend is perceptible in Lagos state, even if there are no available exhaustive data (Fourchard and Olukoju, 2007). Consequently more traders and more markets had come under the grip of the government in the last three decades.In building new markets, in allocating shops and stalls to traders who were previously tenants of a private landlord, local and state governments have increased their revenues. Theoretically, government shops are less expansive than private shops. In Ibadan, $78 \%$ of the tenants of private shops (117 respondents among 150) declare to pay more than 2,000 Nairas a year whereas $49 \%$ of the tenants of local government shops (81 among 164) pay less than N2,000 (Ibadan survey 2002). Practically however the increasing percentage of shops and stalls owned by the government and the lack of available shops elsewhere have led to rent trafficking. Because of their central position in the markets, some shops are sublet between ten to fifty times the initial price. In Bodija market, a dozen subtenants told us that they could pay $\mathrm{N} 10,000$ to $\mathrm{N} 50,000$ a year to an 'official tenant' who pays only between N1,000 and $\mathrm{N} 2,000$ to the North local government ${ }^{11}$.

Hundreds of thousands of traders are thus concerned by the increasing involvement of government officials in their daily routine. This is well epitomized by the development of bureaucratic regulations on market and street trading (repeated regular banning of street trading, compulsory registration of market association). If the banning of street trading is not necessarily enforced, these by laws provide the legal basis for local government officials to impose taxes on illegal traders. In other words the disregard of by-laws by tens of thousands of traders represents an important albeit not quantifiable source of revenues for local government officials. If Lagos traders did not want to give more details, Ibadan traders were able to describe more precisely the importance of non authorised trade in the political economy of local government taxation:

\footnotetext{
${ }^{11}$ Interviews with shop owners in Bodija market. Ibadan, May 2002.
} 
'The sheds constructed illegally are mostly owned by traders who cannot afford to rent shops. Most of these illegal shed traders pay a token to the local government in form of bribes. Receipts for revenue collected from them by the Revenue Officers are not issued. These illegal shed owners pay as much as 100 Naira per month to these revenue officers. For street traders who got their space illegally, the government may decide to send them away at any given time. Health officers only go to the street traders to extort money from them without properly inspecting the state of the market. When local government staff comes to collect money from them they are always obliged to give such illegal fee without requesting for receipt as street traders are not ready to lose their space'. ${ }^{12}$

As more traders became involved in local government taxation market women came into political limelight. Lagos market women became politicised when the first political party of the 1920s mobilises women influence for his own partisan politics. Women's influence however, was still limited. When the franchise was extended to women in 1950, it suddenly gave more power to women and especially to market women, who constituted a majority of women voters in southern Nigerian cities. The politicisation of market women progressed to the point to which they formed an auxiliary wing in every major party in Lagos (Baker, 1974: 241, Mba, 1987). Market women have been a strong support of the dominant party in Lagos (AG and its successive off-shots), a party perceived as protecting their interest against colonial, federal and military government drastic measures. They backed Awolowo in the 1950s and 1960s, awoits Lateef Jakande and Bola Ige, respectively governors of Lagos and Oyo state during the Second Republic and awoist Bola Tinubu, governor of Lagos state (1999-2007) and son of the leader of the state market women's association (Baker, 1974; Mba, 1987; Fourchard and Olukoju, 2007). Conversely, military regimes especially the Buhari regime (1983-1985) and its Lagos military governor, Gbolahan Mudashiru, did not hesitate for the opposite reason to demolish stalls and illegal shops, to set mobile courts to sanction thousands of illegal vendors and to organise punitive violent raids againt illegal traders (Fourchard 2007a). The last governor of Lagos state, Babatunde Fashola, is also initiating a programme of removing 'disorderly and environmentally unfriendly elements' in the metropolis but many observers consider that this project is only possible because the Governor had just been elected. ${ }^{13}$

The politics of motor parks

Since the 1950s, local government councils are statutorily charged with the responsibility for establishing, maintaining and collecting rates at motor parks in Nigeria. The management of motor parks became a central place of political antagonism during the Second Republic when motor park management was taken over by transporters unions. It should also be noted that the 1970s represent for Lagos and most other southern cities the definitive decline of former means of transport (bicycles, municipal buses and train) taken over by a network of private owners of mini buses locally called danfo.

The politicisation of the management of motor parks started in Lagos as the capital was the place of two concurrent powers: the Federal government, the president Shehu Shagari, and his party, the National Party of Nigeria (NPN) on the one hand, and the governor of Lagos State, Lateef Jakande and the UPN on the other hand. NPN decided to enlist the support of members of a new union, the Nigerian Union Road Transport Workers (NURTW) created a year before, in 1978 under the leadership of Adebayo Ogundare, known as Bayo Success who was giving the assignment of winning all the motor parks in Lagos over the UPN (Albert, 2007: 129-130). He did so in mobilising his large clientele of drivers during the

\footnotetext{
${ }^{12}$ Summary of interviews with traders, shop owners and street traders in Bodija. May 2002.

${ }^{13}$ I would like to thank Rufus Akinyele for informing me on this point.
} 
1979 electoral campaign and in resorting to violence and killing his potential opponents in most of motor parks in Lagos. Bayo Success planted his clients as chairmen in each of the parks and became the chairman of Oshodi branch of the union before being arrested by the military regime in 1983 (Akinyele, 2008). The practice of hiring drivers of the union as thugs was not restricted to Lagos as NURTW extended his operations to the five other southwestern states (Ogun, Oyo, Bendel, Ondo and Kwara) during the Second Republic.

Since the return of a civilian regime in 1999, the position of NURTW chairman is highly contested between the two main political forces in South Western Nigeria, the AD/ AC and the PDP. The relationship between union chairmen and governors are shaped by a set of contractual client/patrons deals. As the main patron in the state is generally the governor, most of NURTW union chairmen have tended to align with the governor and/or with his godfather. Influential patrons often referred as 'big men' have large clientele of people who deliver services in exchange of material and non materials rewards. This redistribution of money, food, position and contracts has become central in the political economy of Nigeria especially with the growth of structural unemployement and poverty since the 1980 s even if the figure of the big man is more ancient in this region (Barber, 1991). Like during the $2^{\text {nd }}$ Republic, NURTW chairmen act mainly as provider of thugs recruited among the union drivers to assist the governor during his electoral campaigns, to intimidate and if necessary to kill political opponents. In exchange union chairmen are given money for his 'garage boys' as well as a large autonomy for levying taxes in the motor parks of the state. The fortune of motor park's chairman is however highly volatile and dependant from the fluctuation of the local political landscape.

In Lagos, NURTW is dominated by the Lagos state party (AD/ AC) and any attempt by the PDP to uproot the union from the influence of the party has until date failed. The killing of Saka Kaula in January 2008, Lagos state chapter of the NURTW and AC supporter, led the following week to clashes between factions supported by the two rival parties which led to several deaths and to the postponement of local government election by the state governor. ${ }^{14}$ In Ibadan, the situation is more complicated. Lamidi Adesina (AD) became governor of Oyo State in 1999 largely because of the support he got from NURTW through its chairman, Alhaji Lateef Akinsola alias 'Tokyo' (Albert, 2007: 141). But in Ibadan as in Lagos and other Nigerian cities, motor parks are political contested places: on the $15^{\text {th }}$ September of 2001, a failed coup planned by the PDP to take over the motor parks over AD led to the killing of maybe 300 people. ${ }^{15}$ In 2003, a PDP governor was eventually elected mainly because of the support of godfather Lamidi Adedibu whose personal fortune and direct connection with President Obasanjo has changed him into the main patron of Ibadan politics (Omobowale and Olutayo, 2007). Tokyo, the former NURTW chairman was arrested while another leader of NURTW came to support the new PDP governor. Consequently during the 2007 election, NURTW members were recruited as political thugs by Lamidi Adedibu, to help rigging the elections in favour of his new PDP governor's candidate which eventually won the election. ${ }^{16}$

Union leaders are thus narrowly connected to state politicians and local government officials according to a deal that satisfy the main actors but which has nothing to do with the planning of the city or the transportation system. The collection of taxes at motor parks is at the discretion of the local chairman of the union. The local government fixed a monthly sum to be given by the union in exchange for the power given to the union to levy taxes on motor

\footnotetext{
14 'Lagos paralysed: NURTW chairman, Saula, murdered', Nigerian Tribune, 8 January 2008; 'Violence as thugs set Oshodi market ablaze - Over murder of NURTW chairman', Nigerian Tribune, 9 January 2008.

${ }^{15}$ Personal observation, Ibadan, September 2001 and interview with Isaac Olawale Albert, Ibadan, May 2003.

${ }^{16}$ Interviews with AC leaders in Ibadan and PDP militants and thugs in Adedibu's palace, Molete, Ibadan, April 2007.
} 
parks. Each driver is obliged to pay the owo ita (union levy) to union officials (some of the members advance the sum of 500 naira without any reward). ${ }^{17}$ Drivers report this tax on the price of the tickets while the amount of this legal extortion remains unknown. So far, no investments have been made for the improvement of motor parks and transportation system in most of southern Nigerian cities. The fruitful business of motor park exploitation has led to the proliferation of motor parks all over Lagos (there are probably more than one thousand today) and Ibadan since the 1980s and increased congestion dramatically, as they have generally been positioned along major roads, closed to markets or crossroads (Albert, 2007).

\section{Conclusion}

The decline of the urban infrastructure of Lagos is less the result of the weakness of the Nigerian state than a combination of three interrelated political issues. Firstly, the obsession of the first set of independent leaders with projecting a modern image for Lagos, which was limited to a few projects. Secondly, the financial neglect of the capital by the Federal government since the 1970s. Thirdly, the historical opposition between the Federal government and Lagos state leaders concerning the allocation of resources to the Lagos state and local governments. This opposition also led to a politicisation of urban space in which the control of some key spaces has more to do with the electoral agenda of major political parties than with the planning of the city. Allocations to the local councils have been taken over by the Federal government in the last four years and since 2008 by Lagos state government. Taxation on markets has generally increased in the last three decades and collection of fees at motor parks has been outsourced by local and state governments to transport union leaders for political reasons. The resources of the city, instead of being invested for the improvement of infrastructure, have been used for the building of political networks between state officials and a number of 'civil society' leaders. In my view, this process and the reinforcement of taxation are less a manifestation of informality and state decline than they are parts of the historical state formation in Nigeria and in Lagos in particular.

Lagos was neither an orderly colonial or postcolonial city nor is today a paradigmatic African city which has escaped the former colonial order. If Koolhaas' team has tried in a way to rehabilitate the Lagos informal economy, their perception is a romanticised rereading of the history of the city which underestimates the ceaseless denunciation by Lagosian themselves of the successive failures of their mass transportation and housing systems. More importantly Koolhaas's team has depoliticised the history of Lagos. Conflicts over the use of the space are absent and the omnipresence of state officials and political party leaders ignored. Lagos works especially for those who are able to extract money from the use of public space according to a web of client/patron relationships that still need to be explored in a more detailed analysis.

\section{References}

Abrams, C., Kobe S., Koenigsberger O., Shapiro M. and Wheeler M. (1980) Metropolitan Lagos. Habitat International 55, 55-83.

Abumere, S.I. (1989) The new federal capital territory: regional development and planning. In T. Tamuno and J.A. Atanda (eds.), Nigeria since Independence. The first 25 years, Heinemann, Ibadan.

Adebayo, A.G. (1987) Lagos: the choice and position of a federal capital. In A. Adefuye, B. Agiri and J. Osuntokun (eds.), History of the Peoples of Lagos State, Lantern Books, Lagos.

\footnotetext{
${ }^{17}$ Olu Osunde, 'NURTW, Law into itself ?', Nigerian Tribune, 24 February 2008.
} 
Akinyele R. (2008), Ecology of crime: Oshodi-Mafoluku axis of Lagos, unpublished paper, Lagos.

Albert, I. O. (2007) NURTW and the politics of motor parks in Lagos and Ibadan. In L. Fourchard (ed.) Gouverner les villes d'Afrique. Etat, gouvernement local et acteurs privés, Paris, Karthala.

AlSayyad, N. (2004) Urban informality as a 'new' way of life. In A. Roy and N. Alsayyad (eds.), Urban Informality: Transnational Perspectives from the Middle East, Latin America and South Asia. Lexington Books, New York.

Bach, D. C. (2006) Inching towards a country without a state: prebendalism, violence and state betrayal in Nigeria. In C. Clapham, J. Herbst et G. Mills (eds.), Big African States, Wits University Press, Johannesburg.

Baker, P. H. (1974) Urbanization and Political Change: The Politics of Lagos, 1917-1967. University of California Press, Berkeley.

Barber, K. (1991), I Could Speak Until Tomorrow Orik:, Women and the Past in a Yoruba Town. Smithsonian Institution Press, Washington.

Barnes, S. (1986) Patrons and Power: Creating a Political Community in Metropolitan Lagos. Manchester University Press, London.

Bayart, J. F. (1993) The State in Africa. The Politics of Belly. Longman, London.

Bello-Imam, I. B. (1996) Local Government in Nigeria. Evolving a Third Tier of Government. Heinemann, Ibadan.

Benna, U. G. (1989) The federal capital; the debate and the planning. In T. Tamuno and J.A. Atanda (eds.), Nigeria since Independence. The first 25 Years, Heinemann, Ibadan.

Chen, A.C. (2001) Women in the informal sector: a global picture, the global movement, School of Advances International Studies Review, 221, 1, 71-82.

Chen, M. A. (2006) Rethinking the informal economy: linkages with the formal economy and the formal regulatory environment. In B. Guha-Khasnobis, R. Kanbur, and E. Ostrom (eds), Linking the Formal and Informal Economy. Concepts and Policies. Oxford University Press, Oxford.

Clapham, C., Herbst J. and Mills G. (eds.) (2002) Big African States. Wits University Press, Johannesburg.

Crawford, Y. (2004) The end of the post-colonial state in Africa? Reflections on changing African political dynamics. African Affairs, 103, 410, 23-51.

Crook, R. \& Manor, J. (1998), Democracy and Decentralisation in South Asia and West Africa: Participation, Accountability and Performance. Cambridge University Press, Cambridge.

De Boeck, F. (2006) La ville de Kinshasa, une architecture du verbe, Esprit, 12, 79-105.

Diamond, L. Kirk-Greene, A. and Oyediran, O. (eds.) (1997) Transition without End: Nigerian Politics and Civil Society Under Babangida, Lynne Rienner, Boulder.

Ferguson, J. (2007) Formalities of Poverty: thinking about social assistance in Neoliberal South Africa. African Studies Review 50, 2, 71-86.

Fourchard, L. (2007a) Les rues de Lagos : espaces disputés/espaces partagés. Flux 66-67, 6272.

Fourchard, L (2007b) Violences et ordre politique au Nigeria. Politique Africaine 106, 5-28.

Fourchard, L. (ed.) (2007c) Gouverner les villes d'Afrique. Etat, gouvernement local et acteurs privés. Karthala, Paris.

Fourchard, L et X. Godard (2002) Lagos ou les séquelles de la rente pétrolière. In X. Godard (ed.), Les transports et la ville en Afrique au sud du Sahara. Paris, Karthala.

Fourchard, L and Olukoju A, (2007) State, local governments and the management of markets in Lagos and Ibadan. In Fourchard L (ed.) Gouverner les villes d'Afrique, Paris, Karthala.

Gandy, M. (2005) Learning from Lagos. New Left Review 33, 36-52. 
Gandy, M. (2006) Planning, anti-planning and the infrastructure crisis facing metropolitan Lagos. Urban Studies, 43, 2, 371-396.

Grest, J. (1995) Urban management, local government reform and the democratisation process in Mozambique: Maputo city, 1975-1990. Journal of Southern African Studies 21, 1, 147-164.

Guyer, J. (2004) Marginal Gains. Monetary Transactions in Atlantic Africa. University of Chicago Press, Chicago.

Hagopian, F. (2007) Parties and voters in emerging democracies. In C. Boix and S. C. Strokes (eds.), The Oxford Handbook of Comparative Politics, Oxford University Press, Oxford.

Hansen, K. and Vaa M. (eds.) (2004) Reconsidering informality: Perspectives from Urban Africa, Nordic Africa Institute, Upsala.

Hansen, K. (2004) Who rules the streets? The politics of vending space in Lusaka. In K Hansen and M Vaa (eds.) op. cit.

Haynes, J. (2007) Nollywood in Lagos, Lagos in Nollywood films. Africa Today 54, 2, 131 149.

Heilbrunn, J .R. (1997) Commerce, politics, and business associations in Benin and Togo, Comparative Politics, 29, 4, 473-92.

Hibou, B. (ed.) (1994), Privatising the State. Hurst, London.

Hofmeyr, B., and Pauwels, M. (2002) To be or not to be modern? Journal of Literary Studies. $18,1-2,1-24$.

Joseph, R. A. (1987), Democracy and Prebendal Politics in Nigeria: the Rise and Fall of the Second Republic. Cambridge University Press, Cambridge.

Kitschelt, H. and Wilkinson, S. (eds.) (2007) Patrons, Clients and Policies: Pattern of Democratic Accountability and Political Competition. Cambridge University Press, Cambridge.

Konu, K. (2002), Regenerating downtown Lagos. In Enwezor, O. et al. (eds) (2002), Under Siege: Four African Cities. Freetown, Johannesburg, Kinshasa, Lagos, Hartje Cantz Publishers, Ostfildern-Ruit.

Koolhaas, R. and al (2000) Lagos, Harvard Project on the City. In Koolhaas, and al (eds.), Mutations, événement culturel sur la ville contemporaine. Arc en Rêve, Centre d'architecture, Bordeaux.

Koolhaas, R. (2003) Fragments of a lecture on Lagos. In Enwezor, op. cit.

Lagos State (1981) Fourth National Development Plan, 1981-1985: Lagos State Programmes, Ikeja.

Lagos State (2006) Lagos Island Central Business District Revitalisation, Lagos.

Larkin, B. (2004) Degraded images, distorted sounds: Nigerian video and the infrastructure of piracy. Public Culture, 16, 2, 289-314.

Lewis, P. (1996) From prebendalism to predation: the political economy of decline in Nigeria. Journal of Modern African Studies 34, 1, 79-103.

Lindell, I. (2008) The multiple sites of urban governance: insights from an African city. Urban Studies 2008, 45-9, 1879-1901.

Loada, A. and Otayek, R. (1995) Les élections municipales du 12 février 1995 au Burkina Faso. Politique africaine, 58, 135-142.

Lund C. (2007) Twilight institutions: an introduction. In C. Lund (ed.) Twilight Institutions:

Public Authority and Local Politics in Africa, Blackwell, Oxford.

Mamdani, M. (1996) Citizen and Subject: Contemporary Africa and the Legacy of Late Colonialism. Princeton University Press, Princeton.

Mann, K. (2007) Slavery and the Birth of an African City, Lagos, 1760-1900. Indiana University Press, Bloomington and Indianapolis. 
Maris, P. (1962) Family and Social Change in an African City. A Study of Rehousing in Lagos. Northwestern University Press, Evanston.

Mba N. M. (1987), Women in Lagos political history. In A. Adefuye, B. Agiri, J. Osuntokun op. cit.

,Nations Unies (1999), Conseil Economique et Social, Commission de la population et du développement.

Olowu, D. (1990) Lagos State, Governance, Society and Economy. Malthouse Press Limited, Lagos.

Olukoju, A. (2003) Infrastructure Development and Urban Facilities in Lagos, 1861-2000. IFRA, Ibadan.

Omobowale A.O. and Olutayo A.O. (2007), Chief Lamidi Adedibu and patronage politics in Nigeria. Journal of Modern African Studies, 45, 3, 425-446.

Osaghae, E. (1998) Crippled Giant. Nigeria since Independence. Hurst, London.

Packer, G. (2006) The Megacity; decoding the chaos of Lagos, The New Yorker, November 13.

Peil, M. (1991) Lagos: The City Is the People. Belhaven Press, London.

Rao, V. (2006) Slum as theory: the South/Asian city and globalization. Review essay. International Journal of Urban and regional Planning. 20,1, 225-232.

Rakodi, C. (1997), Global forces, urban change, and urban management in Africa. In C. Rakodi (ed.) The Urban Challenge in Africa Growth and Management of its Large Cities. United Nations University Press, New York.

Rakowski, C. (1994) The informal sector debate, part 2: 1984-1993. In C. Rakowski (ed.)

Contrapunto; the Informal Sector Debate in Latin America. State University of New York, Press, Albany.

Reno, W. (1998) Warlord Politics and African States. Lynne Rienner, Boulder and London.

Robinson, J. (2006) Ordinary Cities. Between Modernity and Development. Routledge, London.

Roitman, J. (2007) The right to tax: economic citizenship in the Chad Basin, Citizenship Studies, 11, 2, 187-209.

Scheiner, E. (2006) Democracy without Competition in Japan. Opposition Failure in a OneParty Dominant State. Cambridge University Press, Cambridge.

Simone, A. (2004) For the City Yet to Come. Changing African Life in Four Cities. Duke University Press, Durham and London.

Sindzingre, A. (2006) The relevance of the concepts of formality and informality: a theoretical appraisal. In B. Guha-Khasnobis, R. Kanbur, and E. Ostrom (eds.), op. cit.

Stokes, S. C. (2005) Perverse accountability: a formal model of machine politics with evidence from Argentina, American Political Sciences Review. 99, 3, 315-325.

Skinner, C. and Valodia, I. (2003) Local government support for women in the informal economy in Durban, South Africa, International Journal of Politics, Culture and Society, 16, 3, 431-444.

Suberu R. (2001) Federalism and Ethnic Conflict in Nigeria, United States Institute of Peace Press, Washington.

Thrift, N. (2005) But malice aforethought: cities and the natural history of hatred. Transactions of the Institute of British Geographers 30, 2, 133-150.

Tripp A.M. (1997) Changing the Rules: The Politics of Liberalisation and the Urban Informal Economy in Tanzania. University of California Press, Berkeley and Los Angeles.

Udo, R. (2000), Population Census in Nigeria: Depoliticization, Ebieakwa Ventures, Lagos. Vagale L. R. (1974) Anatomy of Traditional Markets in Nigeria: Focus on Ibadan City, Polytechnic, Ibadan. 
Walle, van de N. (2001) African Economies and the Politics of Permanent Crisis. Cambridge University Press, Cambridge.

Zelela, P. (1999) The spatial economy of structural adjustment in African cities. In P. Zelela and E. Kalipeni (eds.), Sacred Spaces and Public Quarrels: African Cultural and Economic Landscapes. Africa World Press, Trenton. 